RESEARCH ARTICLE

\title{
Morphological evidence for the taxonomic status of the Bridge's Guan, Penelope bridgesi, with comments on the validity of $P$. obscura bronzina (Aves: Cracidae)
}

\author{
Oscar Diego Evangelista-Vargas ${ }^{1}$, Luís Fábio Silveira ${ }^{1}$
}

\author{
'Seção de Aves, Museu de Zoologia da Universidade de São Paulo, São Paulo, Brasil. Avenida Nazaré 481, Ipiranga, \\ 04263-000 São Paulo, SP, Brazil. \\ Corresponding author: Diego Evangelista-Vargas (diegoevangelistav@gmail.com)
}

http://zoobank.org/C4A2862F-20E9-47CE-AA81-AE74C6AFEC84

\begin{abstract}
Penelope obscura Temminck, 1815 is a forest guan found in Brazil, Paraguay, Uruguay, Argentina and Bolivia. Three subspecies are currently recognized: Penelope o. obscura Temminck, 1815, P. o. bridgesi Gray, 1860, and P. o. bronzina Hellmayr, 1914. The limits between Penelope taxa are poorly understood since few studies have evaluated their differences in plumage, distribution and taxonomy. Based on 104 specimens deposited in ornithological collections we studied the variations in the plumage of $P$. obscura, including all characters that have been used to describe the included subspecies. Our results show that the plumage of these birds is extremely variable in southern and southeastern Brazil. Without any morphological and morphometric characters to support $P$. o. bronzina as a valid taxon, we synonymized it with $P$. obscura. Conversely, P. o. bridgesi, which occurs in the Yungas and the Chaco, is a distinct taxon and should be treated as a separate species from $P$. obscura.
\end{abstract}

KEY WORDS. Distribution, morphology, Penelope, taxonomy.

\section{INTRODUCTION}

Penelope obscura Temminck, 1815 is distributed from eastern Minas Gerais and northern Espírito Santo in Brazil, to southeastern Paraguay, northeastern Argentina (extending to central Bolivia) and Uruguay (Del Hoyo and Kirwan 2016). As it is often the case among members of the genus, $P$. obscura is syntopic with other species throughout its distribution: on the eastern slopes of the Andes of Bolivia and northwestern Argentina, this species shares its habitat with $P$. montagnii and $P$. dabbenei, and in southeastern Brazil, eastern Paraguay and northeastern Argentina, it is usually found with $P$. superciliaris (Vaurie 1968).

The body plumage of $P$. obscura is usually dark brown; neck, mantle, upper wing coverts and breast are edged with dull white, as the forehead and eyebrow. The tarsus is blackish brown or black in life (Vaurie 1968). It presents sexual dimorphism in the color of the iris, red to orange in males and brown or dark brown in females, which is already well differentiated in the first year of life (Sick 1997, Chalukian 1997, Nacinovic 2012).
Based on the "Yacuhú" of Azara (1805), Temminck (1815) described $P$. obscura. Paraguay is considered as its type locality. Gray (1860) described Penelope bridgesi, type locality in Bolivia (restricted to Villa Montes, Tarija by Vaurie 1966). Ogilvie-Grant (1893) suggested that $P$. bridgesi should be considered a synonym of $P$. obscura; however, Hartert and Venturi (1909) considered $P$. bridgesi as a subspecies of $P$. obscura, a placement that is currently accepted. Finally, Hellmayr (1914) described P. obscura bronzina based on a specimen collected in Santa Catarina (Colonia Hansa, currently Corupá). The author also delimited the geographic distribution of the three subspecies. Hellmayr's hypotheses (1914) have been adopted up to now, and no revisions of Penelope have been published since the taxonomic study of Vaurie (1968).

Penelope obscura bronzina is an endemic subspecies of the Brazilian Atlantic Forest and has a wide distribution, occurring from east of Minas Gerais to Santa Catarina through Espírito Santo, Rio de Janeiro, São Paulo and Paraná (Sick and Teixeira 1979). The nominate form is distributed in southern Brazil, in the states of Santa Catarina and Rio Grande do Sul, also including the forested regions in Paraguay, Uruguay and northeastern 
Argentina (in the provinces of Misiones, Chaco, Corrientes, Entre Ríos and Santa Fe); the exact range of this subspecies in Brazil is unclear, but it is most likely restricted to the forests of the Paraná and Uruguay Rivers. Lastly, P. o. bridgesi occurs in western South America, being found in the Bolivian Yungas in the provinces of Cochabamba, Santa Cruz, Chuquisaca and Tarija, and towards the south in Argentina in the forests of eastern slopes of the Andes in the provinces of Jujuy, Salta, Tucumán and Catamarca. The gap between the ranges of this and the two other subspecies may have been caused by an increase of the aridity in the Chaco, which has isolated this taxon in the Andean foothills (Vaurie 1968).

Vaurie (1966) recognized that the nominate subspecies differs from $P$. $o$. bronzina by having the feathers of the head entirely blackish with only a suggestion of light edgings on the forehead and brows. Penelope o. bronzina, according to this author, has the head with long and bordered feathers, especially on the anterior half of the crown, with silvery-white. Also, the race obscura would be smaller in size and lighter, with plumage browner and throughout duller. Other authors such as Delacour and Amadon (2004) documented that P. o. bridgesi is similar to P. o. bronzina, being larger and having the crest feathers less edged with white and little or no trace of eyebrow stripe, with the plumage duller and browner.

Del Hoyo and Kirwan (2016) mentioned that plumage differences among races suggest that more than one species may be involved in the $P$. obscura complex. They also pointed out that the possibility of contact and intergradation of the two eastern races, $P$. o. bronzina and $P$. o. obscura, required detailed study. Vaurie (1968) suggested that these races do not intergrade, and Del Hoyo and Motis (2004) noted a gap between the two forms in the state of Santa Catarina, Brazil, and also recognized the need of studies to evaluate the taxonomy of this complex.

\section{MATERIAL AND METHODS}

We analyzed and measured 80 museum specimens of all taxa currently considered as belonging to the P. obscura complex (36 males, 29 females and 15 of unknown sex), all of which are distributed in Brazil, Argentina, Paraguay and Bolivia. These specimens are housed in the following institutions: Museu de Zoologia da Universidade de São Paulo (MZUSP, including the topotype of P. o. bronzina), São Paulo, Brazil; Museu Nacional da Universidade Federal do Rio de Janeiro (MNRJ), Rio de Janeiro, Brazil; Museu de História Natural do Capão da Imbuia (MHNCI), Curitiba, Brazil; Museu de Ciências Naturais da Fundação Zoobotânica do Rio Grande do Sul (MCNRS), Porto Alegre, Brazil; and Museo Argentino de Ciencias Naturales "Bernardino Rivadavia" (MACN), Buenos Aires, Argentina. Photographs of the specimens were taken against a white background using 10 watt LED spotlights, always in the same place to standardize the lightening. We also examined photographs of 24 specimens, including the holotypes of $P$. o. bronzina and $P$. o. bridgesi, deposited in the following institutions: Museum für Naturkunde (MFN), Berlin, Germany; Field Museum of Natural History (FMNH), Chicago, USA; Rijksmuseum van Natuurlijke Historie (RNHL), Leiden, Netherlands; Zoologische Staatssammlung München (ZSM), Munich, Germany; and the Natural History Museum (BMNH), Tring, UK (Fig. 1).

Localities and geographic coordinates were obtained from the labels attached to the specimens. When the coordinates were not available they were obtained by consulting ornithological gazetteers (Paynter and Traylor 1991, Paynter 1992, 1995, Vanzolini 1992). The maps were designed using the software QGis 2.6.0, showing the divisions of countries, Brazilian states and the biogeographic provinces proposed by Morrone (2009) to differentiate the areas where the taxa occur. In order to perform detailed analysis of geographic variations in body size and plumage coloration we defined nine geographic groups considering morphological homogeneity, geographic proximity and ecological similarity. Specimens identified as juveniles by distinct plumage and smaller sizes were excluded from the morphometric and plumage analyses, and were considered only to compile the distribution of the taxa.

We measured the length of the exposed culmen, bill from nostril, tarsus, middle toe, wing and tail using calipers with precision of $0.01 \mathrm{~mm}$ following Baldwin et al. (1931). Morphometric data were analyzed to test the sexual dimorphism and intra- and inter-geographic group variations. Shapiro-Wilk and Lilliefors (Kolmogorov-Smirnov) tests were performed to test the normality of data. Sexual dimorphism in each group was evaluated through the Student's t test, testing the differences between sexes for each selected character. For multivariate analyses, the data requires log-transformed variables as input so that all of them have the same relevance for the analysis. Multivariate analyses are based on multiple variables that are measured in the same individual and are not independent from each other, and we tested the general morphology of $P$. obscura with all the morphometric variables taken together. To corroborate the sexual dimorphism we performed the Hotelling's T square test, the multivariate counterpart of Student's t, testing the differences between the multivariate means. A Lineal Discriminant Analysis (LDA) was also used; this test identifies all the elements that belong to each geographic group (including each measure for each variable) and generates a linear combination of variables that can find the pattern within the data and effectively classify it. It represents in percentages the possibility of individuals belonging to the pre-determined group or meeting the pattern of another group. The Canonical Variates Analysis (CVA) was performed to check whether the groups form significantly distinct clusters morphometrically. The univariate part of the tests was conducted in R software statistical package v. 3.2.1 and the multivariate analysis was carried out in Past v. 2.15.

The plumage was evaluated according to the Munsell Color Guide (1994), based on traits usually considered as diagnostic for the three subspecies: supercilium, crown, throat, breast, abdomen, back, tail and wing coverts. We also analyzed 


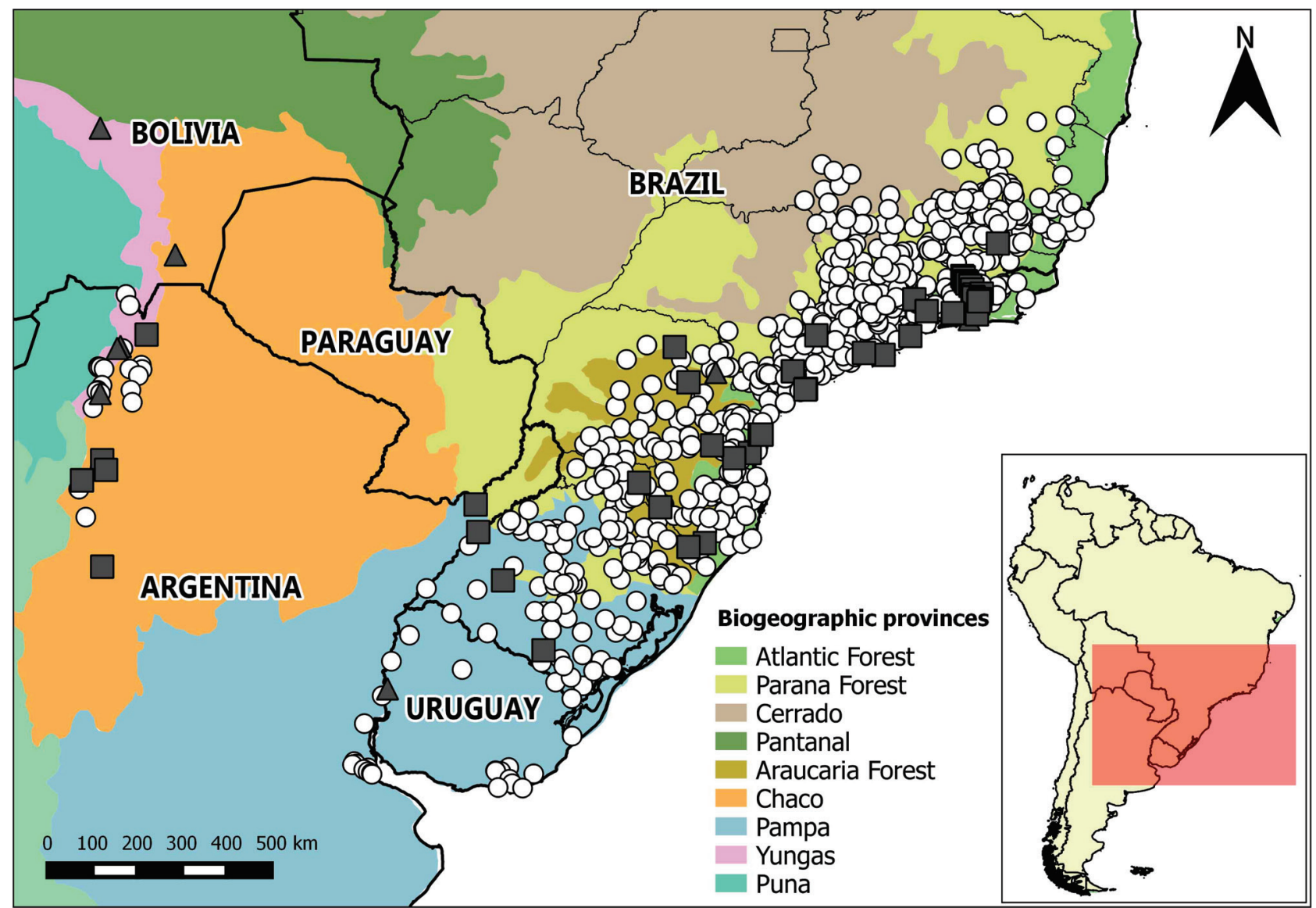

Figure 1. Distribution of Penelope obscura. Black squares: specimens analyzed personally; Black triangles: specimens analyzed by photographs; White circles: living individuals (photos).

photographs of living individuals available in the online databases Wiki Aves (http://www.wikiaves.com.br) and Ecoregistros (http://www.ecoregistros.org). From WikiAves were reviewed 4.342 images from the states of Espírito Santo (122), Minas Gerais (976), Rio de Janeiro (711), São Paulo (1.582), Paraná (333), Santa Catarina (274) and Rio Grande do Sul (344) in Brazil; and 100 images from Ecoregistros, for the records in Uruguay (18) and northeast (31) and northwest (51) of Argentina (Fig. 1). Some of the examined photographs were excluded from our analysis because they had been taken from a long distance, were very dark, or portrayed partially or wrongly identified taxa.

\section{RESULTS}

Statistical analyzes: nine geographic groups were defined: three from the Atlantic forest, two from the Araucaria forest, and one from the Parana forest, Pampa, Chaco and Yungas (Table 1). For statistical analyses, we examined 77 adult specimens distributed in the aforementioned biogeographic provinces (Fig.
2). Table 2 presents the descriptive statistical analysis including mean, standard deviation and minimum and maximum values.

Univariate analysis of normality suggests that data of the six variables meet the criteria of the parametric tests. Student's t-test was not performed for the groups with small sample number; it was used to test the null hypothesis that the mean value of each variable does not differ between the two sexes for each group. Based on the test, the vast majority of the means of the two sexes do not differ significantly; only in five specific cases was there a significant difference between the sexes, with males being larger than females (Table 3 ). The $\mathrm{T}^{2}$ Hotelling test has as null hypothesis that the vectors of the means of the sexes are equal, and shows that there is no sexual dimorphism in the same geographic groups tested for Student's t-test ( $p>0.05$ ).

Table 4 presents the results of Lineal Discriminant Analysis and shows that everything in the off-diagonal are the frequencies of individuals that also meet the pattern of other groups. Only 33 (44\%) of the individuals were correctly classified within their pre-determined group. The MANOVA/CVA explained 


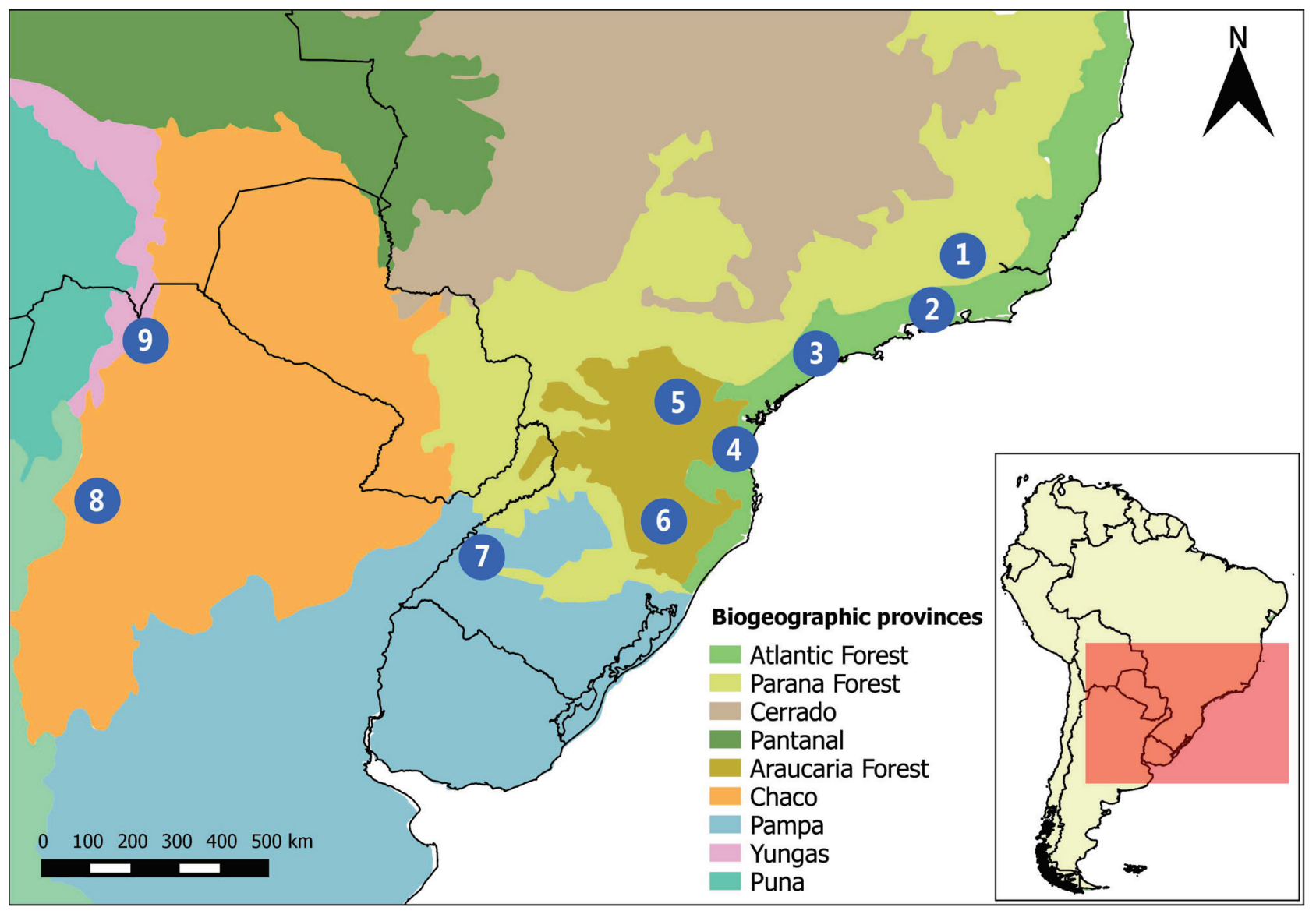

Figure 2. Geographic groups of Penelope obscura separated by biogeographic provinces: Parana forest (1), Atlantic Forest (2,3,4), Araucaria Forest (5,6), Pampa (7), Chaco (8) and Yungas (9).

Table 1. Geographic groups and respective number of skins used for statistical analysis.

\begin{tabular}{|c|c|c|}
\hline Geographic groups & Number and gender & Localities \\
\hline 1. Parana Forest & 8 (4 males, 4 females) & Southeast of Minas Gerais (Brazil) \\
\hline 2. Atlantic Forest 1 & $\begin{array}{l}24 \text { ( } 14 \text { males, } 8 \\
\text { females, } 2 \text { unknown) }\end{array}$ & Northeast of São Paulo (Brazil) \\
\hline 3. Atlantic Forest 2 & $\begin{array}{l}11 \text { ( } 5 \text { males, } 6 \\
\text { females) }\end{array}$ & East of São Paulo (Brazil) \\
\hline 4. Atlantic Forest 3 & 5 ( 1 male, 4 unknown) & $\begin{array}{c}\text { East of Paraná and Northeast of } \\
\text { Santa Catarina (Brazil) }\end{array}$ \\
\hline 5. Araucaria Forest 1 & $\begin{array}{c}5 \text { (1 male, } 2 \text { females, } 2 \\
\text { unknown) }\end{array}$ & $\begin{array}{c}\text { Central Paraná and North of Santa } \\
\text { Catarina (Brazil) }\end{array}$ \\
\hline 6. Araucaria Forest 2 & 4 ( 1 male, 3 females) & $\begin{array}{l}\text { Center Santa Catarina and Northeast } \\
\text { of Rio Grande do Sul (Brazil) }\end{array}$ \\
\hline 7. Pampa & $\begin{array}{l}7 \text { (4 males, } 2 \text { females, } \\
1 \text { unknown) }\end{array}$ & $\begin{array}{l}\text { Southwest of Rio Grande do Sul } \\
\text { (Brazil) and Misiones (Argentina) }\end{array}$ \\
\hline 8. Chaco & $\begin{array}{l}11 \text { ( } 6 \text { males, } 4 \\
\text { females, } 1 \text { unknown) }\end{array}$ & Tucumán and Catamarca (Argentina) \\
\hline 9. Yungas & 1 (unknown) & Salta (Argentina) \\
\hline
\end{tabular}

the variations between the geographic groups in the first two axes, and most of them could not be differentiated by any of the morphometric variables. Groups 6 and 7 from southern Brazil and northeastern Argentina (Araucaria forest and Pampa, respectively) differed slightly from the others in the length of the tail (Fig. 3).

Specimens collected in eastern South America showed continuous distribution with no gap in the state of Santa Catarina in Brazil. Their plumage showed no sexual dimorphism in any geographic group. The characters used to diagnose the subspecies $P$. o. obscura were found in specimens from various parts of its wide range. For instance, the whitish edges of head feathers are wide (MZUSP 31577, from Varjão de Guaratuba, São Paulo, BR), thin (MZUSP 34130, Maromba, Rio de Janeiro, BR) or almost imperceptible (MACN 44036, Chantecler, Misiones, ARG), without any apparent geographic trend. The overall color of the crown feathers affects the appearance of the head, which can be black, gray, or brown. In addition, the prominence of the white 
Table 2. Mean, standard deviation, minimum and maximum values of body measurements $(\mathrm{mm})$ from the geographic groups of Penelope obscura.

\begin{tabular}{|c|c|c|c|c|c|c|}
\hline $\begin{array}{c}\text { Geographic } \\
\text { groups }\end{array}$ & Exposed culmen & Nostril & Tarsus & Middle Toe & Wing & Tail \\
\hline $1(n=8)$ & $29.04 \pm 2.62(26.2-33.1)$ & $25.41 \pm 1.83(23.3-27.6)$ & $75.41 \pm 5.83(70.2-88.6)$ & $62.38 \pm 2.39(59-67)$ & $314.75 \pm 14.51(292-338)$ & $357.38 \pm 10.25(342-372)$ \\
\hline $2(n=24)$ & $30.24 \pm 2.70(24.9-35.1)$ & $24.52 \pm 1.66(21.6-27.3)$ & $76.35 \pm 4.10(68.4-83.1)$ & $66.75 \pm 3.35(62-73)$ & $324.3 \pm 15.89(295-360)$ & $356.4 \pm 19.23(321-410)$ \\
\hline $3(n=11)$ & $32.16 \pm 1.49(30-34.7)$ & $25.21 \pm 1.22(23.7-27.8)$ & $80.73 \pm 2.07(76.2-82.8)$ & $69.54 \pm 1.86(67-72)$ & $324.7 \pm 25.68(293-362)$ & $346.2 \pm 23.62(322-385)$ \\
\hline $4(n=5)$ & $32.1 \pm 2.41(29-35)$ & $25.68 \pm 1.70(23.1-27.2)$ & $84.32 \pm 3.54(78.7-87.2)$ & $71 \pm 4.74(63-75)$ & $326.8 \pm 14.20(306-343)$ & $346 \pm 16.98(321-368)$ \\
\hline $5(n=5)$ & $27.42 \pm 2.74(23.2-30.4)$ & $22.66 \pm 1.98(20.5-24.8)$ & $79.96 \pm 3.90(77-86.7)$ & $66.8 \pm 4.15(61-72)$ & $320.2 \pm 20.90(299-347)$ & $356.6 \pm 19.77(330-384)$ \\
\hline $6(n=4)$ & $25.95 \pm 0.87(25.2-27.2)$ & $22.3 \pm 0.22(22-22.5)$ & $77.65 \pm 3.13(74-81.2)$ & $64.75 \pm 2.5(62-68)$ & $311.25 \pm 16.68(287-324)$ & $311.5 \pm 16.98(288-327)$ \\
\hline $7(n=7)$ & $25.81 \pm 1.23(23.9-27.7)$ & $22.7 \pm 0.81(21.4-23.7)$ & $79.01 \pm 2.33(77.1-83.3)$ & $65.86 \pm 2.91(61-70)$ & $322.4 \pm 17.35(297-345)$ & $323 \pm 15.06(299-339)$ \\
\hline $8(n=11)$ & $27.16 \pm 1.03(25.9-28.5)$ & $22.66 \pm 1.18(21.1-24.5)$ & $76.86 \pm 3.32(71.2-81.4)$ & $63.4 \pm 3.96(58.2-70)$ & $329.5 \pm 18.13(295-346)$ & $355.3 \pm 15.03(328-376)$ \\
\hline $9(n=1)$ & 26.1 & 23.3 & 81.8 & 68 & 346 & 368 \\
\hline
\end{tabular}

Table 3. Student t-test comparing males and females of each geographic group with more than four individuals for each sex. Asterisks indicates significant differences between both sexes at $\mathrm{p}<0.05$.

\begin{tabular}{cccccccc}
\hline $\begin{array}{c}\text { Geographic } \\
\text { group }\end{array}$ & $\begin{array}{c}\text { Exposed } \\
\text { culmen }\end{array}$ & Nostril & Tarsus & $\begin{array}{c}\text { Middle } \\
\text { Toe }\end{array}$ & Wing & Tail \\
\hline $1(3: 4,+: 4)$ & $\mathrm{t}=-1.730$ & $\mathrm{t}=-2.006$ & $\mathrm{t}=-0.118$ & $\mathrm{t}=0.137$ & $\mathrm{t}=-0.971$ & $\mathrm{t}=0.921$ \\
& $\mathrm{p}=0.134$ & $\mathrm{p}=0.091$ & $\mathrm{p}=0.91$ & $\mathrm{p}=0.895$ & $\mathrm{p}=0.369$ & $\mathrm{p}=0.392$ \\
& $\mathrm{t}=-1.448$ & $\mathrm{t}=-0.354$ & $\mathrm{t}=-1.132$ & $\mathrm{t}=-3.248$ & $\mathrm{t}=-2.388$ & $\mathrm{t}=-1.047$ \\
$2\left(\delta^{*}: 14,+9: 8\right)$ & $\mathrm{p}=0.163$ & $\mathrm{p}=0.727$ & $\mathrm{p}=0.27$ & $\mathrm{p}=0.004^{*}$ & $\mathrm{p}=0.027^{*}$ & $\mathrm{p}=0.307$ \\
& $\mathrm{t}=-2.342$ & $\mathrm{t}=0.116$ & $\mathrm{t}=-0.409$ & $\mathrm{t}=-0.084$ & $\mathrm{t}=-1.160$ & $\mathrm{t}=-1.430$ \\
$3\left(\delta^{*}: 5,+\circ: 6\right)$ & $\mathrm{p}=0.044^{*}$ & $\mathrm{p}=0.910$ & $\mathrm{p}=0.692$ & $\mathrm{p}=0.935$ & $\mathrm{p}=0.276$ & $\mathrm{p}=0.186$ \\
& $\mathrm{t}=-0.468$ & $\mathrm{t}=-1.756$ & $\mathrm{t}=-0.533$ & $\mathrm{t}=-0.620$ & $\mathrm{t}=-3.367$ & $\mathrm{t}=-2.968$ \\
$8\left(\delta^{*}: 6,+: 4\right)$ & $\mathrm{p}=0.652$ & $\mathrm{p}=0.117$ & $\mathrm{p}=0.608$ & $\mathrm{p}=0.552$ & $\mathrm{p}=0.010^{*}$ & $\mathrm{p}=0.018^{*}$ \\
\hline & & & & & &
\end{tabular}

Table 4. Frequency of percentages of predictive performance from the Lineal Discriminant Analysis (LDA) for all the geographic groups.

\begin{tabular}{ccccccccc}
\hline \multirow{2}{*}{ Predicted } & \multicolumn{7}{c}{ Original } \\
\cline { 2 - 9 } & $\mathbf{1}$ & $\mathbf{2}$ & $\mathbf{3}$ & $\mathbf{4}$ & $\mathbf{5}$ & $\mathbf{6}$ & $\mathbf{7}$ & $\mathbf{8}$ \\
\hline 1 & 50.0 & 12.5 & - & - & - & - & - & 9.1 \\
2 & 37.5 & 62.5 & 27.3 & - & 20 & - & 28.6 & 36.4 \\
3 & - & 8.3 & 54.5 & 80 & 40 & - & - & - \\
4 & 12.5 & - & 9.1 & - & - & - & - & - \\
5 & - & 4.2 & - & - & - & - & - & 9.1 \\
6 & - & - & - & - & - & 25 & 28.6 & - \\
7 & - & 8.3 & 9.1 & 20 & - & 75 & 28.6 & - \\
8 & - & 4.2 & - & - & 40 & - & 14.2 & 45.4 \\
\hline
\end{tabular}

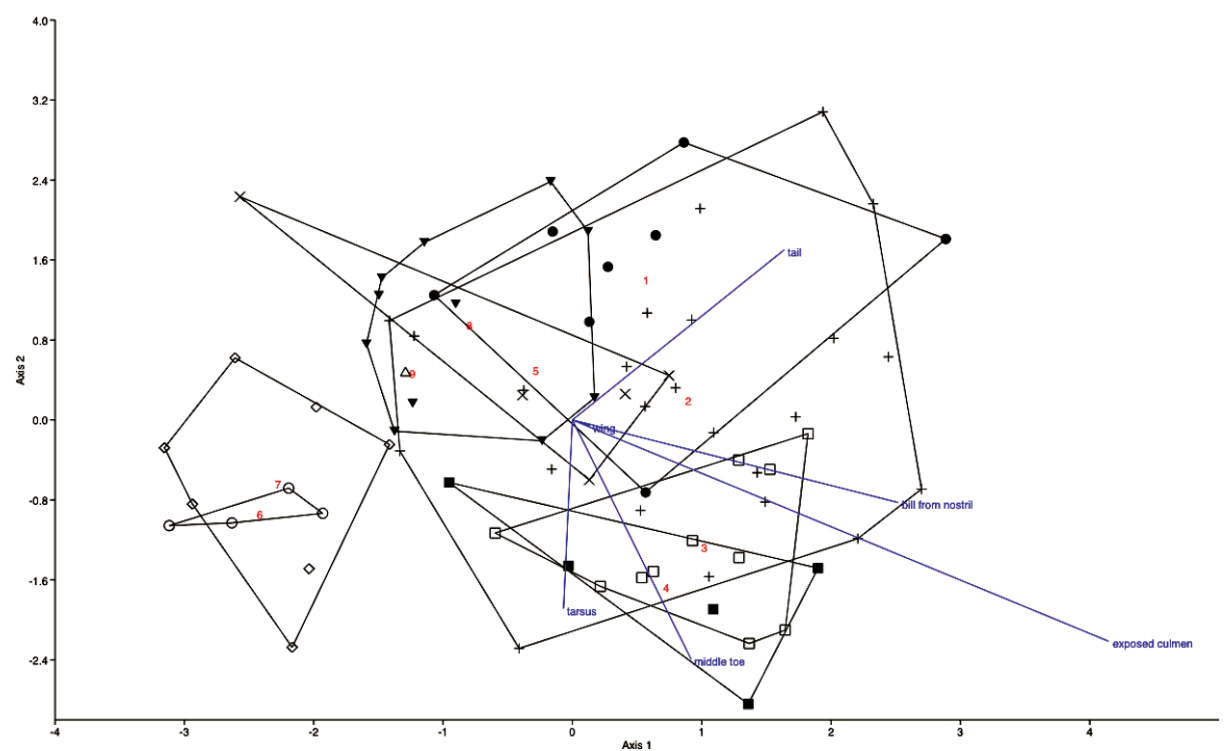

Figure 3. CVA Plot of geographic groups according to morphometric measurements. Black circles: Parana Forest (group 1); Plus: Atlantic Forest 1 (group 2); White squares: Atlantic Forest 2 (group 3); Black squares: Atlantic Forest 3 (group 4); Exes: Araucaria Forest 1 (group 5 ); White circles: Araucaria Forest 2 (group 6); White diamonds: Pampa (group 7); Inverted black triangles: Chaco (group 8); White triangle: Yungas (group 9). 

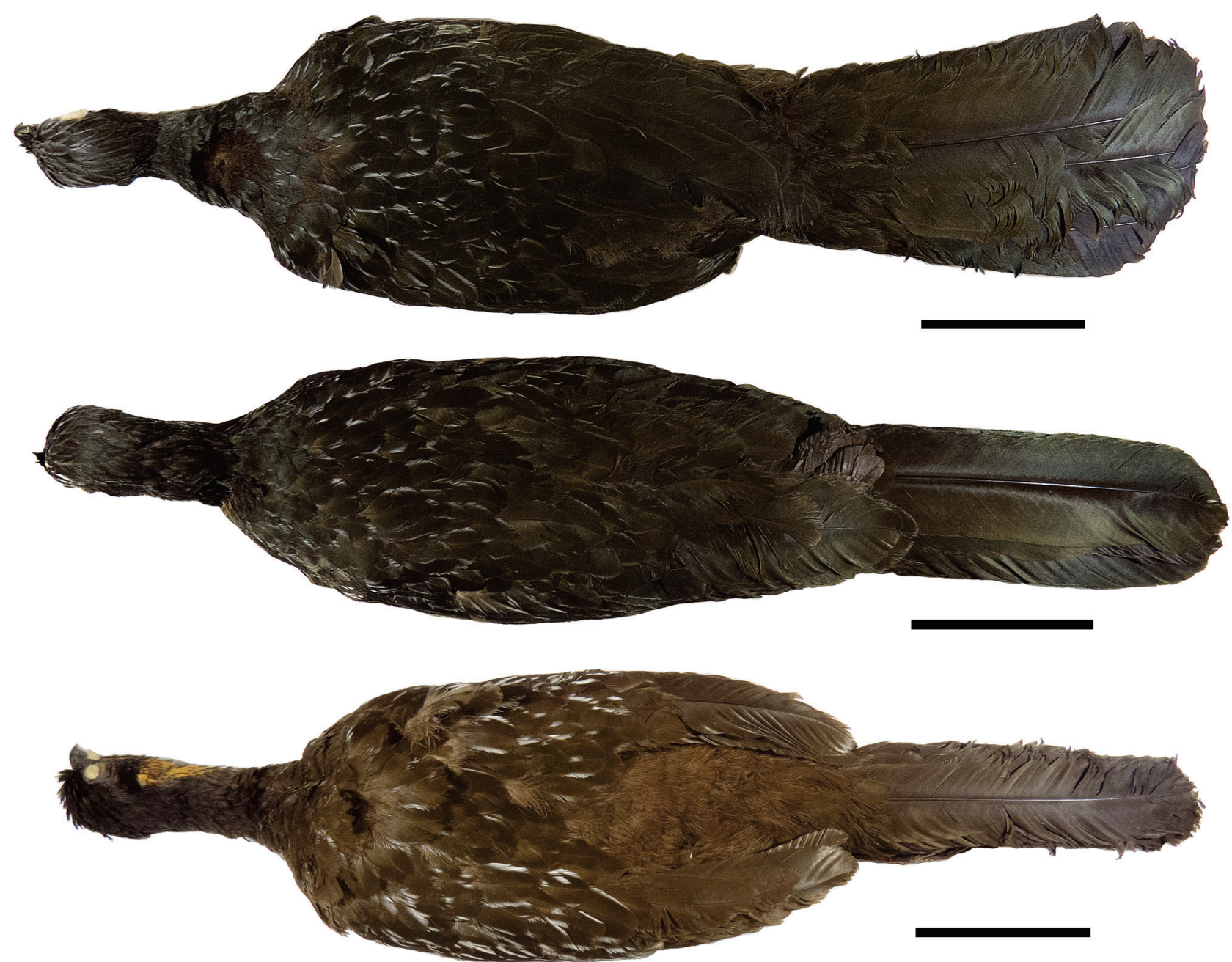

Figure 4. From top to bottom, dorsal view of P. o. bronzina (MZUSP 49384, São Paulo, southeastern BR), P. o. obscura (MACN 48384, Corrientes, northeastern ARG), and P. o. bridgesi (MACN 8148a, Tucumán, northern ARG). Scale bars: $10.0 \mathrm{~cm}$.

hue in the edge of the feathers appears to vary considerably. Specimens from Potreirinhos in Rio Grande do Sul (MCNRS 682, $\mathrm{BR})$ to the south often have less noticeable whitish edges and tend to have a blackish general coloration, but this pattern is also recorded in birds from the northern portion of the range, which present general blackish coloration and feathers with white edges reduced or absent (WA700594, WA823706). On the other hand, specimens in the south of the range may present feathers with noticeable white edges and general grayish coloration (WA914588, WA1763524, WA1782826; ER10072, ER10141).

The plumage of the back also showed considerable variation, without any apparent geographical pattern. Across the entire range of the species we found individuals with the back greenish-brown (MZUSP 32906, Teresópolis, Rio de Janeiro, BR), brownish (MZUSP 7021, Fazenda Monte Alegre, Paraná, BR) or blackish (MZUSP 49384, Rocha, São Paulo, BR). Apparently, specimens from the northern part of the range have the white streaks on the back more noticeable when compared to the southern specimens. However, we also found specimens in the south with wide white streaks (MCNRS 1765, Bagé, Rio Grande do Sul), and in the north the white streaks in some specimens are almost absent (MN 45542, Simão Pereira, Minas Gerais, BR) (Fig. 4).

Some specimens showed a contrasting dark chest with a paler belly (MN 47672, Matias Barbosa, Minas Gerais; MHNCI 204, Tibagi, Paraná, BR), whereas other specimens had a uniformly colored chest with either a dark belly (MN 49619, Levi Gasparian, Rio de Janeiro; MZUSP 49382, Morretinho, São Paulo; MCNRS 1765, Bagé, Rio Grande do Sul, BR) or a paler, uniform belly (MHNCI 399, Vale do Ivaí, Paraná, BR). Both phenotypes 

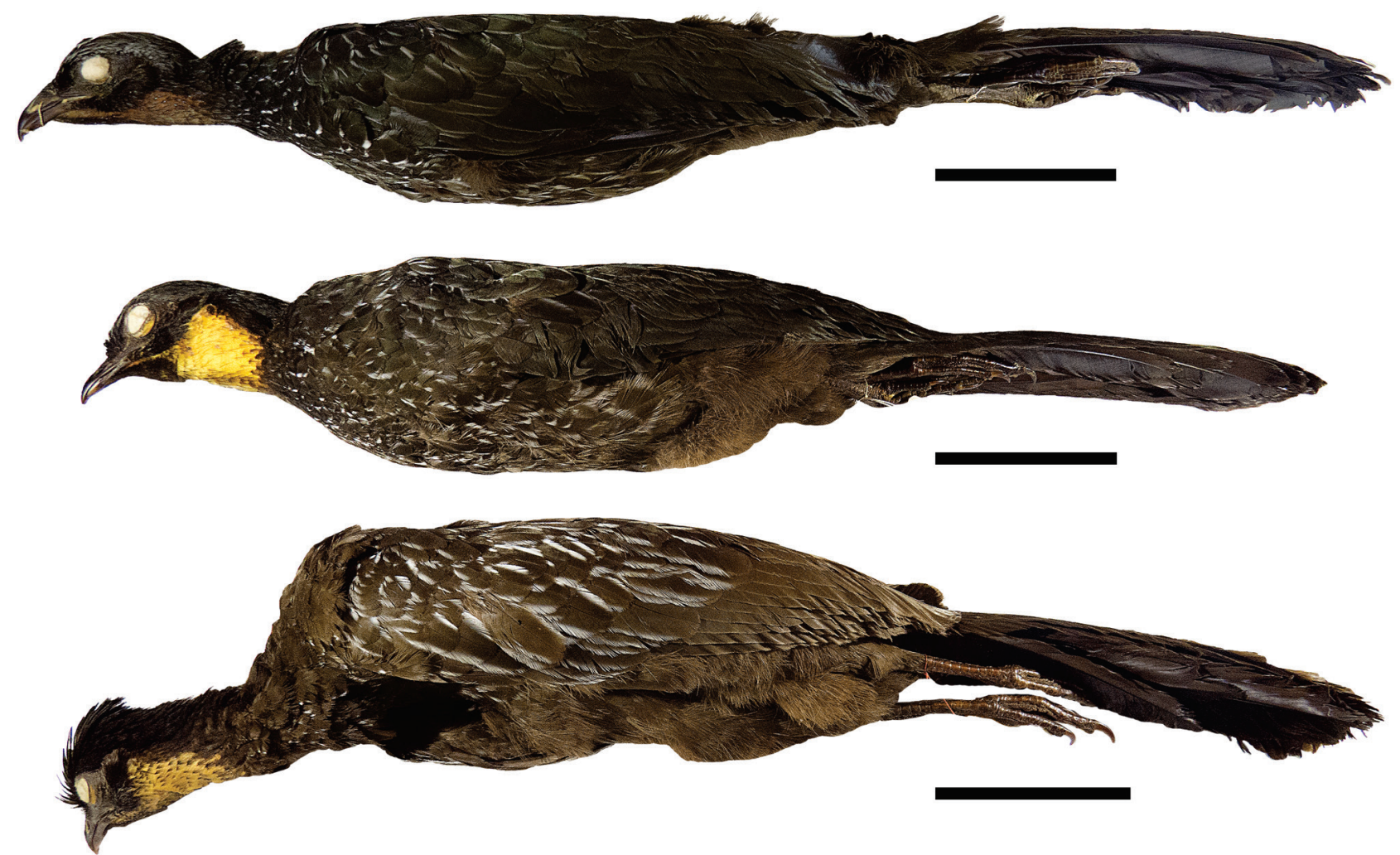

Figure 5. From top to bottom: lateral view of P. o. bronzina (MZUSP 49384, São Paulo, southeastern BR), P. o. obscura (MACN 48384, Corrientes, northeastern ARG), and P. o. bridgesi (MACN 8148a, Tucumán, northern ARG). Scale bars: $10.0 \mathrm{~cm}$.

were found in photographs taken at the same locality (e.g. WA1380991 and WA1423978, from Afonso Cláudio, Espírito Santo, BR). The color of the belly was also variable, ranging from brown (MZUSP 1911, Colonia Hansa, Santa Catarina, BR, topotypical) to orangish (MZUSP 78284, Bananal, São Paulo, BR).

It is common to find individuals with different overall coloration in the same place, demonstrating the existence of a large individual variation (e. g. WA1681568, Pouso Alegre, Minas Gerais; WA450514, Nova Friburgo, Rio de Janeiro; WA1518511, Itatiba, São Paulo; WA1084879 and WA1090972, Tibagi, Paraná, $\mathrm{BR})$. As mentioned before we located specimens with plumage characters supposedly diagnostic for the nominate subspecies in specimens found in the range of $P$. o. bronzina (WA1765142, Bocaina de Minas, Minas Gerais, BR) and specimens with characters considered diagnostic for $P$. o. bronzina in the geographic range of nominate subspecies (ER10141; Ribera del Norte, Buenos Aires, Argentina).

On the other hand, all specimens attributed to P. $O$. bridgesi lacked olive brown coloration with a green tinge to the upperparts (unlike P. o. obscura and P. o. bronzina) (Fig. 4). Instead, specimens of $P$. $o$. bridgesi showed chestnut upperparts contrasting with the black head. The underparts were consis- tently uniform and slightly paler than the back, whereas in $P . o$. obscura and $P$. o. bronzina the coloration of the upperparts was highly variable. The wing coverts of $P$. $o$. bridgesi show broad white margins, a character state not found in P. o. obscura and P. $o$. bronzina, which have indistinct white margins to the wing coverts (Fig. 5). Overall, P. o. bridgesi shows less pronounced individual variation in plumage coloration than $P$. o. obscura and P. o. bronzina.

\section{DISCUSSION}

Misidentifications of Penelope obscura are still common, especially where it is sympatric with $P$. superciliaris. The range of $P$. obscura in eastern South America is continuous, without any gap between the distribution of the nominate race and $P$. $o$. bronzina in southern Brazil (Fig. 1). We suspect that the absence of specimens collected between the states of Santa Catarina (from north, called P. o. bronzina) and Rio Grande do Sul (to south, P. o. obscura), deposited in North American and European museums may have led to the assumption that there was a large geographic gap between the ranges of $P$. o. obscura and $P$. o. bronzina. As no detailed specimen-based study has been conducted to date, 
including analyses of individual and geographic variation, the validity of $P$. obscura bronzina remained uncontested for many decades in the ornithological literature. The same applies to the taxonomic rank of $P$. $o$. bridgesi, an isolated taxon occurring in the biogeographic provinces of Yungas and Chaco on the eastern slopes of the Andes in Bolivia and Argentina, which also was never studied in detail.

The eastern population (P. o. obscura and P. o. bronzina) showed considerable variation in plumage coloration, with many individuals presenting characters previously considered as diagnostic for one of the subspecies in the range of the other. The plumage in P. o. bridgesi was much less variable throughout its range than that of $P$. o. obscura/bronzina. Statistical analyses showed no morphological differences between males and females within the groups, and the few differences among some geographic groups do not represent a pattern of biogeographic variation in the eastern or western populations. We cannot be sure that there is a marked difference in size between the aforementioned subspecies of $P$. obscura, as was previously mentioned by Vaurie (1968). Total size measurements attached to some specimens' labels suggest that males are larger than females, but the color of the iris is the only character that effectively differentiates the two sexes.

The occurrence of $P$. obscura is still questionable in some regions. Sousa (1999) mentioned the presence of this species in Elísio Medrado $\left(13^{\circ} \mathrm{S}, 39^{\circ} 45^{\prime} \mathrm{W}\right)$ in the state of Bahia (Brazil), being the north limit of its distribution. However, as this record was based on a personal communication from a third part, and there are no records from naturalists in the $19^{\text {th }}$ and $20^{\text {th }}$ centuries, when the habitat was undisturbed, we consider unlikely that P. obscura occurs in the state of Bahia since there is no reliable evidence for it. In Paraguay, Hayes (1995) mentioned Penelope obscura as a hypothetical species. It was visually reported in the Chaco (President Hayes, Boquerón) and Orient (Central, Alto Paraná and Neembucú), but unfortunately those reports had no other details. The only specimens mentioned by the author are deposited at the National Museum of Natural History, Smithsonian Institution (USNM 256875, 58994), and they lack precise information on collecting dates and localities, and were obtained at a time when Paraguay included parts of what is now Brazil and Argentina. Smith and Derna (2015) recently reviewed the records in the country and showed that museum skins attributed to $P$. obscura actually represent members of $P$. superciliaris. Recent records from Paraguay are photographs taken in the Refugio de Vida Silvestre Atinguy, in Misiones department $\left(27^{\circ} 20^{\prime} \mathrm{S}\right.$, $56^{\circ} 41^{\prime} \mathrm{W}$ ), claimed by the authors to be wild-origin birds.

After the review of a large series of specimens of $P$. $O$. bridgesi, and by comparing it with $P$. o. obscura and P. o. bronzina, we find that what is currently defined in the literature as Penelope obscura does not include the characters observed in the individuals of P. o. bridgesi. When Ogilvie-Grant (1893) proposed bridgesi as a synonym of Penelope obscura, he only reviewed seven specimens (four from Brazil, one from Uruguay, one from Para- guay, and the holotype from Bolivia), excluding the characters of bridgesi cited by Gray (1860) that are diagnosable to considered it as a species; the same situation was also observed in Hartert and Venturi (1909), which considered it as a subspecies of $P$. obscura. Our results clearly show that Penelope bridgesi is a taxon that can be differentiated from all others without overlapping with any other Penelope. It is geographically isolated and should be treated as a valid species (see below). The populations in eastern and southern Brazil are continuously distributed and show considerable individual variation in plumage, without any clear geographic trend. There are any morphological or morphometric characters to support the continued existence of more than one taxon in the region. As $P$. o. bronzina cannot be distinguished from the nominate subspecies, we here treat Penelope obscura bronzina Hellmayr, 1914 as a synonym of Penelope obscura Temminck, 1815. The treatment proposed here is consistent with the current proposals found for the other species of Penelope.

\section{TAXONOMY}

\section{Penelope obscura Temminck, 1815}

Holotype. The description of the species is based on the 'Yacuhú', made by Azara (1805). Type locality: Paraguay.

Common names. Portuguese: Jacuaçu. Spanish: Pava oscura. English: Dusky-legged Guan.

Diagnosis. Distinguished from P. bridgesi by olive brown coloration with green tinge in upperparts, and generally darker overall coloration. Underparts very variable, unlike $P$. bridgesi. White margins of wing coverts markedly reduced. Head, hindneck, and back coloration more uniform than in P. bridgesi.

Re-description. No sexual dimorphism found in plumage coloration. Whitish edges extension of head feathers varies from wide to almost imperceptible. Some individuals show a moderately distinct superciliary stripe formed by short feathers with white edges. Overall color of crown feathers variable, ranging from black, gray to brown. White hue of the edge of the feathers varies individually. Brown back may show greenish, brownish or blackish tinge. Neck, breast, upper back, and shoulders conspicuously edged with white. Birds in the northern parts of the species' range tend to have more noticeable white streaks on the back, but streaks also may be lacking. The coloration of the underparts is variable and may show a contrastingly darker chest than belly, but underparts may also be uniform dark or lighter than the breast. The belly feathers have contrasting horizontal scaling, which may range from brown to orangish, and may vary in intensity. Tail feathers are dark brown with bronze or purplish sheen. Bare skin of face slaty, legs dusky gray to blackish, and wattle red.

Distribution. Southeastern and southern Brazil (from the east of Minas Gerais and north of Espírito Santo to Rio Grande do Sul), northeastern Argentina (Misiones, Chaco, Corrientes, Entre Ríos, Santa Fe and Buenos Aires), and the forested regions 
of Uruguay, with recent photographic records for Paraguay. Inhabits the biogeographic provinces of Atlantic Forest, Cerrado, Paraná Forest, Araucaria Forest and Pampa.

Examined material $(\mathrm{n}=84)$. BRAZIL. Minas Gerais: Muriaé (1 ㅇ- MNRJ 36791); Juiz de Fora Km.118 (1 ðૂ- MNRJ 45036); Juiz de Fora Km.788 (1 §̊- MNRJ 48346); Matias Barbosa Km.795 (1 §- MNRJ 47672); Matias Barbosa Km.801 (1 q- MNRJ 48384); Simão Pereira Km.807 (1 q- MNRJ 49558); Simão Pereira Km.817 (1 ㅇ- MNRJ 45542, 1 ふో- MNRJ 48997); Simão Pereira Km.825 (1 १- MNRJ 48383); Estação do Túnel (2 \&- BMNH 1901.3.28.65, BMNH 1901.3.28.64); Rio de Janeiro: 2-BMNH 1889.6.1.215,

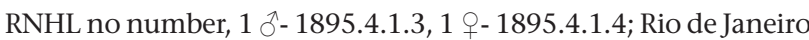
(1 - ZSM no number); Levi Gasparian Km.792 (1 §-MNRJ 49619); Levi Gasparian (1 + - MNRJ 48338); Tres Rios Km.27 (1 + - MNRJ 49080); Areal Km.44 (1 §- MNRJ 49081); Petropolis Km.52 (1 §MNRJ 49574); Petropolis Km.64 (1 ð̊- MNRJ 44389); Teresopolis Km.52 (1 q- MNRJ 47743); Teresopolis Km.82 (1 - MNRJ 48354); Teresopolis (2 - MNRJ 9321, MNRJ 9322, 3 §- MZUSP 32905, MZUSP 32906, MZUSP 32907, 2 9- MZUSP 32904, MZUSP 32908;

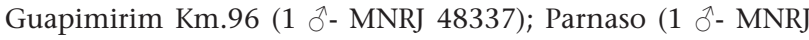
48336); Inga (1 1 - MNRJ 47552); Morro Redondo (1 ㅇ- MNRJ 9405); Maromba (1 ㅇ- MZUSP 34129, 1 ô- MZUSP 34130); Paraty (1 $\widehat{o}$ - MNRJ 36927); São Paulo: 1 - BMNH 1889.6.1.203; Bananal (1 §-MZUSP 78284, 1 - MZUSP 78285); Varjão de Guaratuba (3 ㅇ- MNRJ 31062, MZUSP 31576, MZUSP 43763, 1 ઈ- MZUSP 31577); Cabreúva (1 §- MZUSP 93098); Morretinho e Rocha (2 §- MZUSP 49382, MZUSP 49383, 1 9- MZUSP 49384); Rio Ribeira (1 ㅇ- MZUSP 66890, 1 ઈิ- MZUSP 66891); Icapara (1 ㅇ- MZUSP 73215); Paraná: Vale do Ivai (1 - MHNCI 399); Santa Barbara (1 ̊- MHNCI 251); Fazenda Monte Alegre (1 ô- MZUSP 7021); Tibagi (1 ㅇ- MHNCI 2041); Guaratuba-Caiobá (1 §̂- MHNCI 1189, 2 - MHNCI 256, MHNCI 2519); Santa Catarina: Rio Negro (1 - MHNCI 5776); Joinville (1 ڤึ- RNHL 1292-3, 1 - MZUSP 4863); Colonia Hansa (1 §- ZSM 12415 Penelope obscura bronzina HOLOTYPE, 2 - MZUSP 1911, MFN 2759); Catanduvas (1 MNRJ 36928); Anita Garibaldi (1 \&- MCNRS 2768); Jaguariaiva, Fazenda Morungava (1 - FMNH no number, 1 - 110740); Rio Grande do Sul: Potreirinhos (1 ㅇ- MCNRS 682); Bom Jesus (1 +- MCNRS 2544); São Francisco de Assis (1 - MCNRS 1975); Bagé (1 đ̊- MCNRS 1765). URUGUAY. 1 đ̊- BMNH 1878.1.25.1; Payssandu: 1 - BMNH 1901.2.10.24. PARAGUAY. 1 - BMNH no number. ARGENTINA. Misiones: Chantecler (2 §- MACN 44034, MACN 44036, 1 q- MACN 44035); Corrientes: Rincón Mercedes

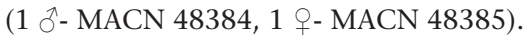

Mentioned photographs. Wikiaves.com.br $(\mathrm{n}=13)$ : BRAZIL. 700594 (Guarapuava, Paraná); 823706 (Caputira, Minas Gerais); 914588 (Taquara, Rio Grande do Sul); 1763524 (Aceguá, Rio Grande do Sul); 1782826 (São Martinho da Serra, Rio Grande do Sul); 1380991 (Afonso Cláudio, Espirito Santo); 1423978 (Afonso Cláudio, Espirito Santo); 1681568 (Pouso Alegre, Minas Gerais); 450514 (Nova Friburgo, Rio de Janeiro); 1518511 (Itatiba, São Paulo); 1084879 (Tibagi, Paraná); 1090972 (Tibagi, Paraná); 1765142 (Bocaina de Minas, Minas Gerais).
Ecoregistros.org $(\mathrm{n}=2)$. ARGENTINA: 10072 (Reserva Ecológica de Ribera del Norte - San Isidro, Buenos Aires); 10141 (Reserva Ecológica de Ribera del Norte - San Isidro, Buenos Aires.

\section{Penelope bridgesi Gray, 1860}

Holotype. BMNH 1846.9.9.42 (sex unknown, Bolivia; examined).

Common name. Spanish: Pava de Bridge. English: Bridge's Guan.

Diagnosis. Distinguished from all members of Penelope by having chestnut-olive brown coloration without green tinge, and overall coloration browner than P. obscura. Underparts are uniform and slightly paler than the back, unlike $P$. obscura. Wing coverts with contrasting large white margins. Black head and hindneck contrast with brownish back, being distinct of P. obscura.

Re-description. No sexual dimorphism found in plumage coloration. General coloration chestnut, with limited individual variation. Crest feathers dark with whitish margins, most strongly marked on the forehead; little or no trace of an superciliary stripe. Upperparts chestnut, contrasting with the black head and hindneck. Lower parts uniform dull reddish brown and slightly paler than the back. The belly feathers have contrasting horizontal scaling, which may range from brown to orangish and may vary in intensity. Feathers of the neck, mantle and chest are margined with white, wider on the mantle and wing coverts. Tail feathers dark brown with brownish sheen. Bare skin of face slaty, legs dusky gray to blackish, and wattle red.

Distribution. Forests of the eastern slopes of the Andes, from central Bolivia (Cochabamba, Chuquisaca and Tarija) to northwest Argentina (Jujuy, Salta, Tucumán and Catamarca). Found in the biogeographic provinces of the Yungas and the Chaco.

Examined material $(\mathrm{n}=20)$. ARGENTINA, Jujuy: Cerro Calilegua (1 §- ZSM 21118); Valle Grande, Ledesma (1 ㅇ- ZSM 59536); Salta: Río Santa María (1 - MACN 30575); Salta (1 우BMNH 1899.1.27.214); Tucumán: Vipos (1 + - MACN 8148a); Tafí Viejo (1 $\widehat{o}$ - MACN 8884); Sierra del Aconquija (1 + - MACN 42153, 4 万-MACN 42156, MACN 42157, MACN 42158, MACN 42159, 1 - MACN 42160); Aconquija (1 ㅇ- MACN 32840); Catamarca: El Suncho (1 3 - MACN 42154, 1 q- MACN 42155). BOLIVIA: Penelope bridgesi HOLOTYPE (BMNH 1846.9.9.42); Cochabamba: Tin-Tin (1 §-FMNH 413837); Tarija: Villa Montes (2 - ZSM 27977, ZSM 27978, 1 ㅇ- MFN 313633).

\section{ACKNOWLEDGMENTS}

We thank Fundação de Amparo à Pesquisa do Estado de São Paulo (FAPESP), Conselho Nacional de Desenvolvimento Científico e Tecnológico (CNPq) and Coordenação de Aperfeiçoamento do Pessoal de Nível Superior (CAPES) for the 
grants received and for the financial support; Idea Wild for the equipment donated to DEV; the photographers who posted the photos in EcoRegistros and WikiAves websites. The curators and staff of the following institutions kindly welcomed us and allowed us to study the specimens under their care: MFN and ZSM (Germany); FMNH (USA); RNHL (Netherlands); BMNH (UK); MACN (Argentina); MNRJ, MHNCI and MCNRS (Brazil). We also thank Instituto Chico Mendes de Conservação da Biodiversidade (ICMBio/SISBIO) for issuing collecting permits. LFS is supported by a CNPq research productivity fellowship. George Sangster kindly reviewed the manuscript and offered important contributions to this text.

\section{LITERATURE CITED}

Azara F de (1805) Caracteres generales de los Yacús. Apuntamientos para la historia natural de los páxaros del Paraguay y Rio de La Plata 3. Doña Manuela Ibarra, Madrid, 69-77.

Baldwin SP, Oberholser HC, Worley LG (1931) Measurements of Birds. Scientific Publications of the Cleveland Museum of Natural History, Cleveland, 165 pp. https://doi.org/10.5962/bhl. title.60247

Chalukian S (1997) Estudio preliminar de La Pava de Monte (Penelope obscura) en el Parque Nacional El Rey, Argentina. In: Strahl SD, Beaujon S, Brooks DM, Begazo AJ, Sedaghatkish G, Olmos F (Eds) The Cracidae, Their Biology and Conservation. Hancock House, USA, 64-70.

Delacour J, Amadon D (2004) Curassows and Related Birds. Second edition. Lynx Edicions, The National Museum of Natural History, New York, 476 pp.

Del Hoyo J, Kirwan GM (2016) Dusky-legged Guan (Penelope obscura). In: Del Hoyo J, Elliot A, Sargatal J, Christie DA, De Juana E (Eds) Handbook of the Birds of the World Alive. http://www. hbw.com/node/53291 [Accessed: 15/11/2016]

Del Hoyo J, Motis A (2004) Update chapter. In: Delacour J, Amadon D (Eds) Curassows and related birds. Lynx Edicions, Barcelona, 322-476.

Gray GR (1860) Penelope bridgesi. Proceedings of the Zoological Society of London 28. Academic Press, London, 270.

Hartert E, Venturi S (1909) Notes sur les oiseaux de la république Argentine. In: Rothschild W, Hartert E, Jordan K (Eds) Novitates Zoologicae XVI. Zoological Museum of Tring, London and Aylesbury, 159-267.

Hayes FE (1995) Status, Distribution and Biogeography of the Birds of Paraguay. American Birding Association, Colorado, 230 pp.

Hellmayr CE (1914) Penelope obscura bronzina new subspecies. In: Rothschild W, Hartert E, Jordan K (Eds) Novitates Zoologicae XXI. Zoological Museum of Tring, London and Aylesbury, 178.

Morrone JJ (2009) Evolutionary Biogeography: An Integrative Approach with Case Studies. Columbia University Press, New York, 304 pp.
Munsell AH (1994) Soil Color Charts. Macbeth Division of Kollmorgan Instruments Corporation, New York, 10 pp.

Nacinovic JB (2012) Uma contribuição iconográfica para a identificação dos Jacus (Aves, Cracidae, Penelope) que ocorrem no Brasil. Agência 2A Comunicação, Rio de Janeiro, 80 pp.

Ogilvie-Grant WR (1893) Catalogue of the Birds in the British Museum 22. Order of the Trustees, London, $585 \mathrm{pp}$.

Paynter RA (1992) Ornithological Gazetteer of Bolivia. Museum of Comparative Zoology of Harvard University, Cambridge, 185 pp. https://doi.org/10.5962/bhl.title.14591

Paynter RA (1995) Ornithological Gazetteer of Argentina. Museum of Comparative Zoology of Harvard University, Cambridge, 1043 pp. https://doi.org/10.5962/bhl.title.14627

Paynter RA, Traylor MA (1991) Ornithological Gazetteer of Brazil. Museum of Comparative Zoology of Harvard University, Cambridge, $788 \mathrm{pp}$.

Sick H (1997) Ornitologia Brasileira. Nova Fronteira, Rio de Janeiro, $912 \mathrm{pp}$.

Sick H, Teixeira DM (1979) Notas sobre aves brasileiras raras ou ameaçadas de extinção. Publicações Avulsas do Museu Nacional 62: 1-39.

Smith P, Derna R (2015) On the status of Dusky-legged guan Penelope obscura Temminck, 1815 (Aves: Cracidae) in Paraguay. Papéis Avulsos de Zoologia do Museu de Zoologia da Universidade de São Paulo 55(14): 211-216. https://doi. org/10.1590/0031-1049.2015.55.14

Sousa D (1999) Novos registros de espécies de aves no estado de Bahia. Atualidades Ornitológicas 88: 6.

Temminck CJ (1815) Histoire naturelle générale des pigeons et des gallinacés 3. Sepp \& Fils, Amsterdam, 757 pp.

Vanzolini PE (1992) A supplement to the ornithological gazetteer of Brazil. Museu de Zoologia da Universidade de São Paulo, São Paulo, 252 pp.

Vaurie C (1966) Systematic notes on the bird family Cracidae. 5, Penelope purpurascens, Penelope jacquaçu, and Penelope obscura. American Museum Novitates 2250: 1-23.

Vaurie C (1968) Taxonomy of the Cracidae (Aves). Bulletin of the American Museum of Natural History 138(3): 131-260.

Submitted: 31 March 2017

Received in revised form: 15 July 2017

Accepted: 28 July 2017

Editorial responsibility: Walter A.P. Boeger

Author Contributions: LFS conceived the study. LFS and DE-V collected the data; DE-V analyzed the data. LFS and DE-V wrote the $\mathrm{ms}$ and gave final approval for publication.

Competing Interests: The authors have declared that no competing interests exist. 